\title{
Forage potential of Urochloa genotypes by using leaf anatomy
}

\section{Janaína Mauri ${ }^{1}$ Daniele Laís Pereira ${ }^{1}$ Gabrielle Avelar Silva ${ }^{1}$ Lisete Chamma Davide $^{1}$ Vânia Helena Techio ${ }^{1}$ Fausto Souza Sobrinho ${ }^{2}$ Fabricio José Pereira ${ }^{3^{*}}$ iD}

${ }^{1}$ Departamento de Biologia, Universidade Federal de Lavras (UFLA), Lavras, MG, Brasil. ${ }^{2}$ Centro Nacional de Pesquisa de Gado de Leite, Embrapa Gado de Leite, Juiz de Fora, MG, Brasil.

${ }_{3}^{3}$ Instituto de Ciências da Natureza, Universidade Federal de Alfenas (UNIFAL-MG), 37130-001, Alfenas, MG, Brasil. E-mail: fabricio.pereira@unifal-mg.edu.br. ${ }^{*}$ Corresponding author.

ABSTRACT: The digestibility potential of leaves from forages depends on the amount of nutrition in their tissues, with low lignin deposition in the cell wall, mainly parenchyma and phloem. This research evaluated the leaf structure of different Urochloa genotypes and discussed its potential for evaluating digestibility. The cultivars U. brizantha, U. decumbens, U. ruziziensis and three clones of U. ruziziensis (1, 95 and 97), which are under development in breeding programs, were evaluated. Plants were grown under the recommended culture conditions for the Urochloa species. Plants were cut 60 days after sowing, and leaves were collected at 15 days of regrowth. Leaves were fixed in FAA 70 and further stored in $70 \%$ ethanol until being submitted to the usual microtechniques for the preparation of microscopy slides. The area of the tissues from the interveinal and midrib regions was measured using ImageJ software, and their proportions were calculated. In the interveinal region, the proportion of chlorophyll parenchyma was greater for U. decumbens and the Clone 1 genotypes. Urochloa brizantha and clones 95 and 97 showed a higher proportion of the vascular bundle compared to U. ruziziensis, U. decumbens and Clone 1 . The proportion of the ground parenchyma in the midrib was greater in U. brizantha, Clone 95 and Clone 97. Thus, it can be concluded that the Clone 1 genotypes (from $U$. ruziziensis) showed leaf tissues (parenchyma and phloem) with higher digestibility potential; in addition, U. brizantha and U. decumbens showed a high percentage of xylem and sclerenchyma, which reduces their quality as forage.

Key words: digestibility, forage production, leaf anatomy, sclerenchyma, lignin.

Avaliação do potencial forrageiro de genótipos de Urochloa por meio da anatomia foliar

RESUMO: O potencial de digestibilidade das folhas de forrageiras depende da quantidade de seus tecidos com baixa deposição de lignina nas paredes celulares, principalmente o parênquima e floema. O presente trabalho objetivou avaliar a estrutura foliar de diferentes genótipos de Urochloa e seu potencial de digestibilidade foliar. Foram avaliadas as cultivares U. brizantha, U. decumbens, U. ruziziensis e três clones de U. ruziziensis $(1,95$ e 97). As plantas foram cultivadas em campo com condições de manejo recomendadas para a espécie, sendo cortadas aos 60 dias e as folhas coletadas aos 15 dias de rebrota. As folhas foram fixadas em FAA 70, armazenadas em etanol 70\% e posteriormente submetidas à microtécnica usual para preparação de lâminas semipermanentes. Foram analisadas as regiões internervural e da nervura mediana com o auxílio do software Image J sendo mensurada a área de cada tecido da folha e depois calculada a sua proporção em relação à área total das secções. Na região internervural, a proporção de parênquima foi maior em U. decumbens e no Clone 1. Ainda nesta região, Urochloa brizantha e os Clones 95 e 97 apresentaram maiores médias para a proporção de feixes vasculares. Na nervura mediana, a proporção do parênquima foi maior em U. brizantha, Clone 95 e Clone 97. De maneira geral, o Clone 1 (proveniente de U. ruziziensis) apresentou parênquima e floema em maiores proporções, enquanto genótipos de U. brizantha e U. decumbens demonstram altas quantidades de xilema e esclerênquima que reduzem o seu potencial de digestibilidade.

Palavras-chave: digestibilidade, forragicultura, anatomia foliar, esclerênquima, lignina.

\section{INTRODUCTION}

Urochloa is a genus that was previously named Brachiaria (SHIRASUNA, 2015) and includes forage species among those most used by livestock breeders in Brazil (VALLE et al., 2009; SOUZA SOBRINHO et al., 2009a). The $U$. brizantha cultivar "Marandu", also of agronomic interest, was released in the 1980s after being developed in Brazilian forage breeding programs (JANK et al., 2005; JANK et al., 2011). Among these forage species (U. ruziziensis, $U$. brizantha, and $U$. decumbens) there is a remarkable effort being expended on the breeding of $U$. ruziziensis because of its high potential for use as forage (JANK et al., 2011; THAIKUA et al., 2015).

The leaves of these cultivars showed high amounts of parenchyma and phloem, which are the main tissues in the diet of cattle because of their primary 
structure and thin cell walls; thus, the leaf anatomy can be a useful tool to assess the digestibility potential of a given forage (PACIULLO, 2002). This assessment is possible because leaf anatomy studies permited comparisons between cultivars in order to estimate their digestibility potential on the basis of the proportions of each leaf tissue (BRITO et al., 2004). Likewise, classical studies that investigated the digestibility of leaf tissues in the rumen solution itself have reported that the degradation of the tissues follows a specific sequence based on cell's structure. This sequence begins with the chlorophyll parenchyma, phloem, epidermis, bundle sheath parenchyma, and, as the least digestible tissues, the xylem and sclerenchyma (HANNA et al. 1973; AKIN, 1989; BRITO et al., 1999; PACIULLO, 2002; PACIULLO et al., 2002). These differences are related to the degree of lignin deposition, which blocks the action of microorganisms, reducing the forage digestibility (GRABBER, 2005; CLIPES et al., 2010). Furthermore, the thickening of the cell wall as well as the tissue arrangement has an impact on the quality of the forage since thicker cell walls and compacted tissues reduce its digestibility (BRITO et al., 1999; PACIULLO, 2002; PACIULLO et al., 2002).

Recent research on the breeding processes of Urochloa includes the plant anatomy as a tool to evaluate the forage potential of the plants and its parts. Among these recent investigations are the investigations of SANTOS et al. $(2013,2014)$ that identified promising genotypes of $U$. ruziziensis for their application to different environmental conditions MAURI et al. (2015) who evaluated the lignin deposition in the cell walls of leaf tissues of $U$. ruziziensis, $U$. brizantha and $U$. decumbens and discussed the lower content of this compound correlating with the quality of the forage, and MAURI et al. (2018) who showed that the age of regrowth influences the proportion of the leaf tissues of $U$. ruziziensis, $U$. brizantha, and $U$. decumbens since longer development times increases the proportion of sclerenchyma and xylem. Thus, including the plant anatomy in the studies for the breeding process of forages permits the selection of plants with higher digestibility and the potential to recover quicker in addition to avoiding the use of animals for in vivo investigations. In this regard, the present work aimed to evaluate the leaf structure of different Urochloa genotypes and discuss their forage potential as related to their anatomical differences.

\section{MATERIALS AND METHODS}

Urochloa brizantha 'Marandu', $U$. decumbens 'Basilisk', and U. ruziziensis 'Kennedy' as well as three $U$. ruziziensis clones (Clone 1, Clone 95 and Clone 97) still under the selection process as part of the Embrapa Gado de Leite breeding program at Juiz de Fora, state of Minas Gerais, Brazil, were obtained. These genotypes were grown in the experimental field of the Embrapa Gado de Leite at Valença, state of Rio de Janeiro, Brazil. The soil used was of a haplic gleysol type that was fertilized and adjusted according to the soil analysis and (MAURI et al., 2018). The soil correction was performed with dolomitic limestone.Fertilization was performed with $300 \mathrm{~kg} \mathrm{ha}^{-1}$ of $\mathrm{NPK}+\mathrm{Zn}$ in the proportion of $08-28-16$, and surface fertilization was further applied using $50 \mathrm{~kg} \mathrm{~N} \mathrm{ha-1}$. Irrigation was performed when the soil moisture was reduced to $50 \%$ of the field capacity, and then water was added to restore its status to $100 \%$ according to previous analyses and the usual management of the experimental area. Standardization cut was performed to the parcels (plants) at 60 days after the experiment implementation, and the fully developed leaves were collected after 15 days of regrowth (MAURI et al., 2018). The experimental design was completely randomized with six treatments (genotypes) and six replicates. The experimental parcel constituted one leaf for each replication.

Leaves were sampled at the second node of the stem apex and fixed in FAA 70 (formaldehyde: glacial acetic acid: $70 \%$ ethanol in the proportion of 0.5:0.5:9 $\mathrm{v} \mathrm{v}^{-1}$ ) for 72 hours (JOHANSEN, 1940). After the fixation period, leaves were stored in $70 \%$ ethanol at room temperature. Leaf transversal sections were performed by hand with steel blades in the basal third of the leaf. This leaf region was selected because the basal part of the leaf has quicker maturation of the sclerenchyma and vascular tissues (BECK, 2010). Sections were clarified with 50\% sodium hypochlorite $\left(\mathrm{v} \mathrm{v}^{-1}\right)$ and washed twice with distilled water for $10 \mathrm{~min}$; sections were then stained with a solution of $0.1 \%$ safranin $\left(\mathrm{m} \mathrm{v}^{-1}\right)$ and $0.9 \%$ astra blue $\left(\mathrm{m} \mathrm{v}^{-1}\right)$ (BUKATSCH, 1972) and mounted on semi-permanent slides with $50 \%$ glycerol $\left(\mathrm{V} \mathrm{v}^{-1}\right)$. Images were obtained from slides using a Leica DMLS microscope (Leica Microsystems Wetzlar $\mathrm{GmbH}$, Wetzlar, Germany) coupled with a Nikon SIGHT DS-SI1 camera. For each replicate, one slide was made and four fields were measured.

Images from the interveinal and midrib regions were analyzed with Image $\mathbf{J}$ software version 1.8.0 (National Institutes of Health, Bethesda, Maryland, USA). This software was calibrated using a micrometric slide that was photographed at the same microscopy configurations used for the sample slides. 
Areas of the tissues were obtained as follows: the adaxial surface of the epidermis, the abaxial surface of the epidermis, the chlorophyll parenchyma, the sum of the phloem areas, the average phloem area in one vascular bundle, the sum of the areas of the vascular bundle sheaths, the sum of the areas of the vascular bundles, the sum of the areas of the xylem, the average xylem area in one vascular bundle, the sum of the area of fibers, the average fiber area in one vascular bundle, and the whole leaf area captured in the image using square micrometers as the measurement unit. To obtain the tissues proportions of , calculations were performed as follows: $\mathrm{TP}=(\mathrm{TA} / \mathrm{LA})^{*} 100$, where: $\mathrm{TP}=$ the proportion of each tissue, $\mathrm{TA}=$ the tissue area, and $\mathrm{LA}=$ the leaf area as measured in the images.

Data were tested for a normal distribution using the Shapiro-Wilk test and then subjected to an analysis of variance; the means were compared by the Scott-Knott test to $P \leq 0.05$. The statistical analysis was performed using the statistical software Sisvar 5.0 (FERREIRA, 2011).

\section{RESULTS AND DISCUSSION}

As shown in table 1, the epidermis proportion in both leaf surfaces at the interveinal region showed no significant differences among the genotypes. However, the chlorophyll parenchyma proportion was larger in $U$. decumbens and the Clone 1 genotypes. In addition, the phloem proportion was higher in $U$. brizantha and Clone 1 compared to the other genotypes; however, the total phloem proportion was higher in $U$. brizantha. The proportion of vascular bundle sheaths was higher in $U$. decumbens compared to the other genotypes. Furthermore, larger means were observed for $U$. brizantha, Clone 95, and Clone 97 for the proportion of vascular bundles compared to the other genotypes. The proportion of total xylem as well as its proportion in one vascular bundle was larger in $U$. brizantha and Clone 97 compared to the other genotypes. In addition, the total proportion of fibers was lower in $U$. decumbens and Clone 1 compared to the other genotypes. Figure 1 shows some of the analyzed variables in the interveinal region. It is clear that the parenchyma proportion was higher in Clone 1 compared to the other genotypes (Figure 1-D). In addition, a higher proportion of fibers and xylem can be observed in the images for $U$. brizantha (Figure 1-A), U. ruziziensis (Figure 1-C), Clone 95 (Figure 1-E), and Clone 97 (Figure 1-F).

The results of the midrib region are shown in table 2. The epidermis proportion on the adaxial and abaxial surfaces was higher in the $U$. decumbens genotype and lower means were reported for Clones 1 , 95 and 97. ome variations were found, such as similar means for the abaxial surface between $U$. decumbens

Table 1 - Proportions of leaf tissues from Urochloa spp. genotypes in the interveinal region.

\begin{tabular}{|c|c|c|c|c|c|c|}
\hline \multirow[t]{2}{*}{ Tissue } & \multicolumn{6}{|c|}{ - } \\
\hline & U. brizantha & U. decumbens & U. ruziziensis & Clone 1 & Clone 95 & Clone 97 \\
\hline $\operatorname{ADE}(\%)$ & $16.30 \mathrm{a}$ & $17.19 \mathrm{a}$ & $16.78 \mathrm{a}$ & $16.04 \mathrm{a}$ & $17.19 \mathrm{a}$ & $17.44 \mathrm{a}$ \\
\hline $\mathrm{ABE}(\%)$ & $8.94 \mathrm{a}$ & $10.01 \mathrm{a}$ & $9.70 \mathrm{a}$ & $9.88 \mathrm{a}$ & $10.01 \mathrm{a}$ & $9.65 \mathrm{a}$ \\
\hline PAR (\%) & $39.84 \mathrm{c}$ & $44.13 \mathrm{a}$ & $41.97 \mathrm{~b}$ & $45.24 \mathrm{a}$ & $38.39 \mathrm{c}$ & $38.30 \mathrm{c}$ \\
\hline PHT (\%) & $2.98 \mathrm{a}$ & $2.06 \mathrm{~d}$ & $2.40 \mathrm{c}$ & $2.52 \mathrm{c}$ & $2.76 \mathrm{~b}$ & $2.66 \mathrm{~b}$ \\
\hline PHVB (\%) & $8.57 \mathrm{a}$ & $7.21 \mathrm{~b}$ & $7.61 \mathrm{~b}$ & $8.72 \mathrm{a}$ & $8.04 \mathrm{~b}$ & $7.68 \mathrm{~b}$ \\
\hline BS $(\%)$ & $50.52 \mathrm{c}$ & $55.29 \mathrm{a}$ & $53.99 \mathrm{~b}$ & $50.96 \mathrm{c}$ & $51.96 \mathrm{c}$ & $52.89 \mathrm{~b}$ \\
\hline VB $(\%)$ & $34.91 \mathrm{a}$ & $28.66 \mathrm{c}$ & $31.54 \mathrm{~b}$ & $28.84 \mathrm{c}$ & $34.40 \mathrm{a}$ & $34.60 \mathrm{a}$ \\
\hline XLT (\%) & $10.03 \mathrm{a}$ & $7.28 \mathrm{~b}$ & $8.27 \mathrm{~b}$ & $8.15 b$ & $7.70 \mathrm{~b}$ & $9.86 \mathrm{a}$ \\
\hline XLVB (\%) & $28.73 \mathrm{a}$ & $25.39 \mathrm{~b}$ & $26.23 \mathrm{~b}$ & $28.17 \mathrm{~b}$ & $22.83 \mathrm{c}$ & $28.50 \mathrm{a}$ \\
\hline FBT $(\%)$ & $5.01 \mathrm{a}$ & $4.51 \mathrm{~b}$ & $4.85 \mathrm{a}$ & $4.42 \mathrm{~b}$ & $4.89 \mathrm{a}$ & $4.74 \mathrm{a}$ \\
\hline FBVB (\%) & $14.54 \mathrm{~b}$ & $15.68 \mathrm{a}$ & $15.32 \mathrm{a}$ & $15.36 \mathrm{a}$ & $14.03 \mathrm{~b}$ & $13.69 \mathrm{~b}$ \\
\hline
\end{tabular}

Means followed by the same letter in the rows do not differ by the Scott-Knott's test to $5 \%$ of significance. Abbreviations: proportion of the adaxial epidermis (ADE\%); proportion of abaxial epidermis (ABE\%); proportion of chlorophyll parenchyma (PAR\%); proportion of the sum of total phloem in the leaf (PHT\%); proportion of the phloem in one vascular bundle (PHVB\%); proportion of the bundle sheath in the vascular bundle (BS\%); proportion of the vascular bundles in the leaf $(\mathrm{VB} \%)$; proportion of the sum of total xylem in the leaf (XLT\%); proportion of the phloem in one vascular bundle (XLVB\%); proportion of the sum of total fibers in the leaf (FBT\%), proportion of the fibers in one vascular bundle (FBFV\%). 


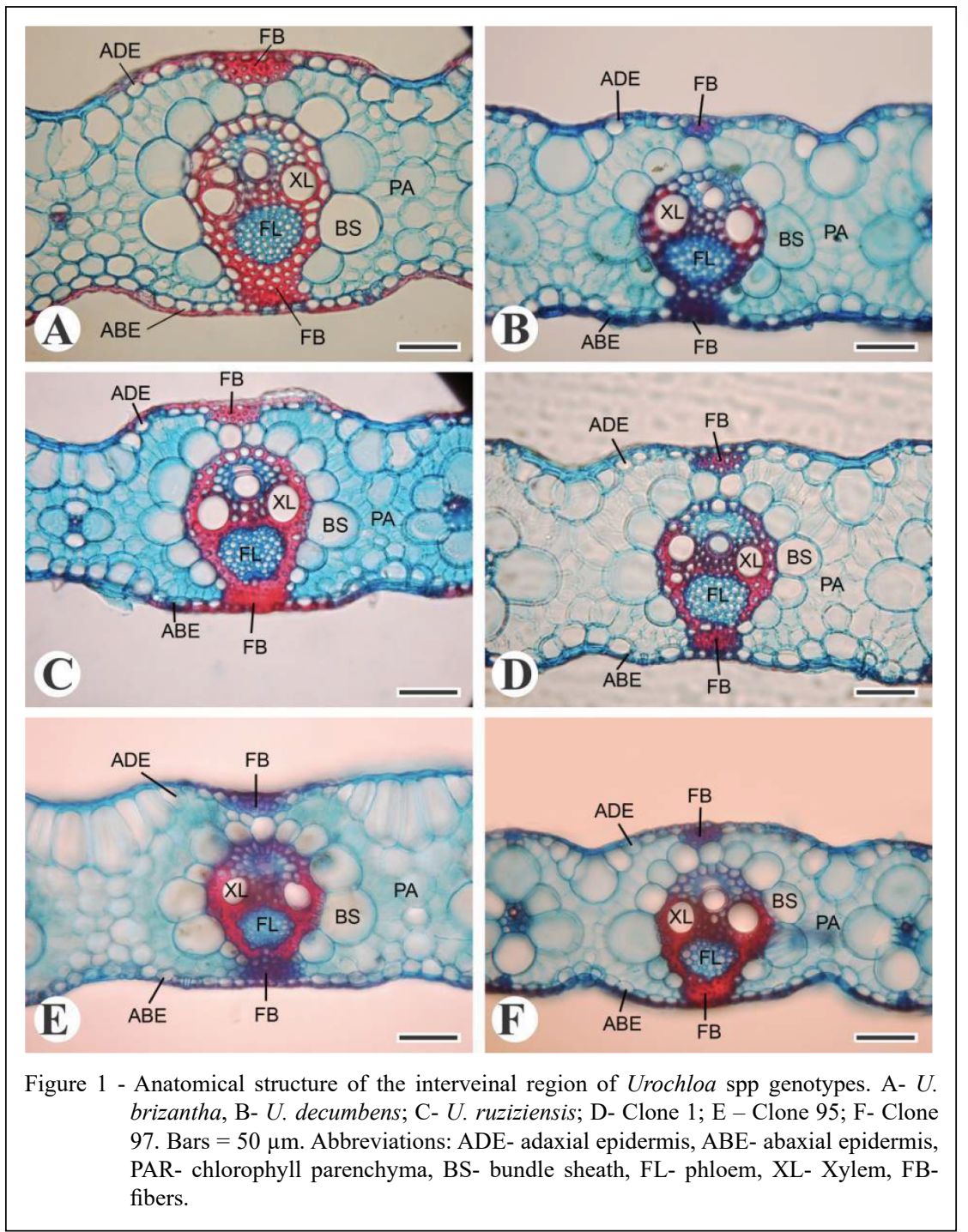

and $U$. brizantha as well as significant differences between the cited clones. In addition, the proportion of ground parenchyma was larger in $U$. brizantha (Figure 2-A), Clone 95 (Figure 2-E), and Clone 97 (Figure 2-F) compared to other genotypes. However, the total phloem proportion and its proportion in one vascular bundle were higher in Clone 1 (Figure 2-D) compared to other genotypes. The proportion of the vascular bundle sheath was larger in $U$. decumbens and $U$. ruziziensis compared to the other genotypes. Furthermore, the vascular bundle proportion was higher in U. decumbens, U. ruziziensis, and Clone 1 compared to other genotypes. The xylem proportion was higher in $U$. decumbens, Clone 1 , and Clone 97 genotypes compared to the other genotypes. A higher proportion of xylem in one vascular bundle was found in $U$. brizantha (Figure 2-A), Clone 1 (Figure 2-D), and Clone 97 (Figure 2-F) compared to the other genotypes. In addition, the fiber proportion was larger in $U$. decumbens, $U$. ruziziensis, and Clone 1 compared to other genotypes whereas the fiber proportion in one vascular bundle was higher in Clones 1 and 97.

According to classical publications that described the sequence of tissue degradation in ruminal liquid (HANNA et al. 1973; AKIN, 1989; BRITO et al., 1999; PACIULLO, 2002 and PACIULLO et al., 2002) it can be noted that, for the interveinal region, the genotypes that showed tissues with higher digestibility potential were $U$. decumbens and Clone 1 because they 
Table 2 - Proportions of leaf tissues from Urochloa spp. genotypes in the midrib region.

\begin{tabular}{|c|c|c|c|c|c|c|}
\hline \multirow[t]{2}{*}{ Tecidos } & \multirow[b]{2}{*}{ U. brizantha } & \multirow[b]{2}{*}{ U. decumbens } & \multirow[b]{2}{*}{ U. ruziziensis } & \multirow[b]{2}{*}{ Clone 1} & \multirow[b]{2}{*}{ Clone 95} & \multirow[b]{2}{*}{ Clone 97} \\
\hline & & & & & & \\
\hline ADE (\%) & $1.18 \mathrm{c}$ & $2.21 \mathrm{a}$ & $1.60 \mathrm{~b}$ & $1.68 \mathrm{~b}$ & $1.57 \mathrm{~b}$ & $1.56 \mathrm{~b}$ \\
\hline $\mathrm{ABE}(\%)$ & $3.30 \mathrm{~b}$ & $3.73 \mathrm{a}$ & $3.89 \mathrm{a}$ & $2.88 \mathrm{c}$ & $2.15 \mathrm{e}$ & $2.64 \mathrm{~d}$ \\
\hline PAR (\%) & $65.15 \mathrm{a}$ & $60.34 \mathrm{c}$ & $60.74 \mathrm{c}$ & $62.42 \mathrm{~b}$ & $65.70 \mathrm{a}$ & $64.91 \mathrm{a}$ \\
\hline PHT (\%) & $1.24 \mathrm{~b}$ & $1.25 \mathrm{~b}$ & $1.38 \mathrm{~b}$ & $1.66 \mathrm{a}$ & $1.11 \mathrm{c}$ & $1.26 \mathrm{~b}$ \\
\hline PHVB (\%) & $5.41 \mathrm{~b}$ & $4.87 \mathrm{c}$ & $5.37 \mathrm{~b}$ & $6.75 \mathrm{a}$ & $4.78 \mathrm{c}$ & $5.33 \mathrm{~b}$ \\
\hline BS (\%) & $50.98 \mathrm{~b}$ & $54.17 \mathrm{a}$ & $54.47 \mathrm{a}$ & $45.96 \mathrm{~d}$ & $52.39 \mathrm{~b}$ & $48.95 \mathrm{c}$ \\
\hline VB (\%) & $23.25 \mathrm{~b}$ & $25.64 \mathrm{a}$ & $25.61 \mathrm{a}$ & $24.56 \mathrm{a}$ & $23.16 \mathrm{~b}$ & $23.80 \mathrm{~b}$ \\
\hline XLT (\%) & $4.26 \mathrm{~b}$ & $4.50 \mathrm{a}$ & $3.90 \mathrm{~b}$ & $4.81 \mathrm{a}$ & $4.07 \mathrm{~b}$ & $4.40 \mathrm{a}$ \\
\hline XLVB (\%) & $18.37 \mathrm{a}$ & $17.48 \mathrm{~b}$ & $15.23 \mathrm{c}$ & $19.62 \mathrm{a}$ & $17.53 \mathrm{~b}$ & $18.62 \mathrm{a}$ \\
\hline FBT $(\%)$ & $7.11 \mathrm{~b}$ & $8.07 \mathrm{a}$ & $8.14 \mathrm{a}$ & $8.45 \mathrm{a}$ & $7.41 \mathrm{~b}$ & $7.09 \mathrm{~b}$ \\
\hline
\end{tabular}

Means followed by the same letter in the rows do not differ by the Scott-Knott's test to 5\% of significance. Abbreviations: proportion of the adaxial epidermis (ADE\%); proportion of abaxial epidermis (ABE\%); proportion of ground parenchyma (PAR\%); proportion of the the vascular bundle (BS\%); proportion of the vascular bundles in the leaf (VB\%); proportion of the sum of total xylem in the leaf (XLT\%); proportion of the phloem in one vascular bundle (XLVB\%); proportion of the sum of total fibers in the leaf (FBT\%).

showed a higher parenchyma proportion compared to the other genotypes. In addition, a higher bundle sheath proportion was observed in $U$. decumbens as well as a higher phloem proportion in Clone 1 compared to the other genotypes. According to GOMES et al. (2011) the parenchymatous tissues and the bundle sheath cells showed large digestibility and are important to identify promising genotypes for nutritive value. However, the $U$. decumbens' large fiber proportion reduces the leaf digestibility potential.

The results for the Clone 1 genotype were particularly remarkable because of its high proportion of parenchyma and phloem, which are the tissues with the highest digestibility potential because of their primary and thin cell walls that are easily digested by the rumen (PACIULLO et al., 2002). This genotype comes from the breeding program of $U$. ruziziensis and shows high market potential due to its forage quality (SOUZA SOBRINHO et al., 2010; JANK et al., 2011).

Urochloa brizantha is another genotype that showed tissues with high digestibility potential, for example, high phloem. However, large areas of xylem and sclerenchyma were also reported in these plants and surpassed the proportion of tissues with good digestibility potential, reducing its forage potential. This conclusion can be stated because forages with higher sclerenchyma and xylem proportions are classified as being of low quality because of the lignin deposition in the cell walls of their tissues, which make it difficult to digest the cells and reduces the exploitation as forage (BAUER et al., 2008; MAURI et al., 2015; MAURI et al., 2018).

The genotypes that showed better results for the midrib region were $U$. brizantha, Clone 95 and Clone 97 (with higher parenchyma proportions) and Clone 1 (with higher phloem proportions) showing larger proportions of tissues with higher digestibility potential. TSUZUKIBASHI et al., (2016) also verified that $U$. brizantha showed high digestibility and larger areas of tissues with higher digestibility potential. This genotype has been developed for several years under breeding programs that selected plant materials to be more efficient as forage and showed higher proportions of tissues with high digestibility potential (low lignin content and thinner cell walls) favoring their quality.

Considering that the highest biomass of the leaf is located at the interveinal region compared to the midrib, it can be noted that Clone 1, from the $U$. ruziziensis species, showed a higher biomass of tissues with better digestibility potential among the evaluated genotypes. The success of this genotype is related to its origin as a promising species from breeding programs, which has been well accepted by cattle and shows high nutritive value (VALLE et al., 2009; JANK et al., 2011). Furthermore, U. ruziziensis permits high genetic variability during the selection of better genotypes of this forage because it is the only species of this genus that is diploid; it is becoming a good alternative for livestock (SOUZA SOBRINHO et al., 2009b). 

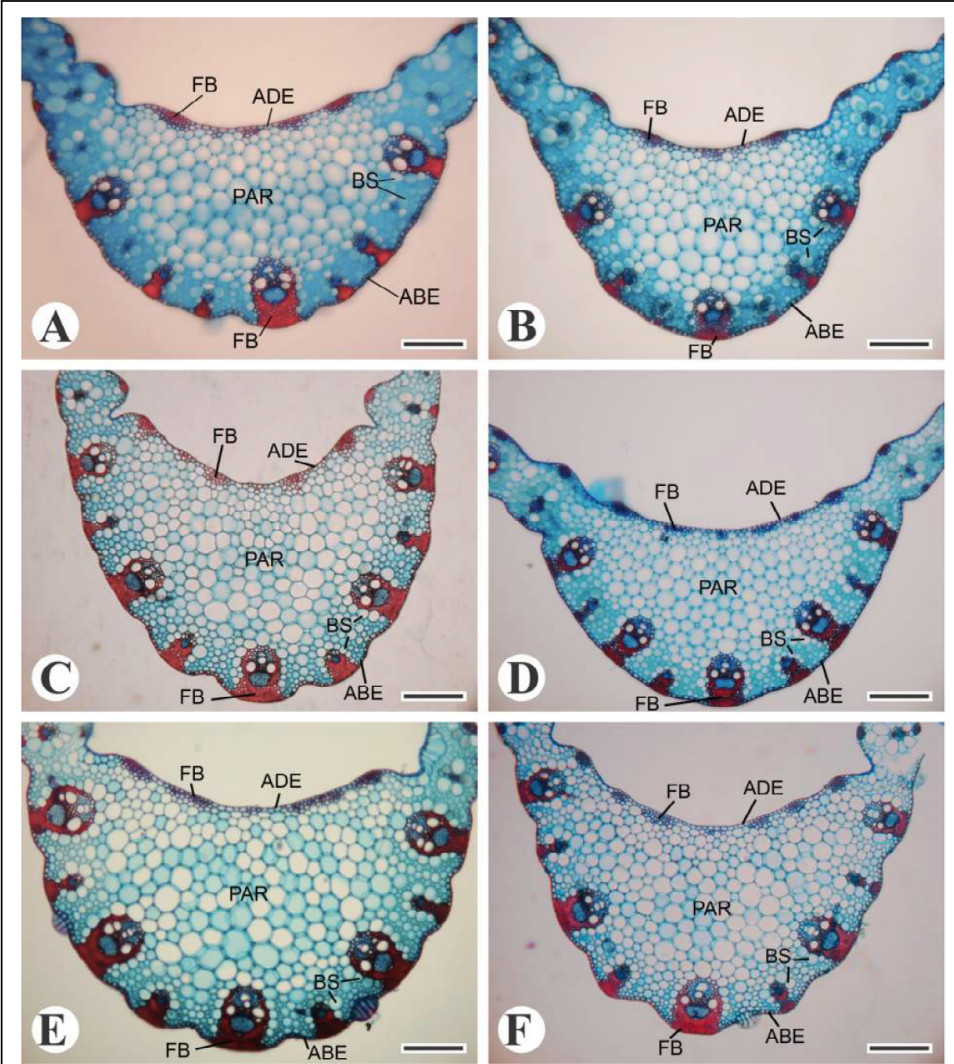

Figure 2 - Anatomical structure of the midrib region of Urochloa spp genotypes. A- U. brizantha, B- U. decumbens; C- U. ruziziensis; D- Clone 1; E Clone 95; F- Clone 97. Bars $=100 \mu \mathrm{m}$. Abbreviations: ADE- adaxial epidermis, ABE- abaxial epidermis, PAR- chlorophyll parenchyma, BSbundle sheath, FL- phloem, XL- Xylem, FB- fibers.

\section{CONCLUSION}

The higher proportion of parenchyma and phloem, particularly in the leaf interveinal region, showed that Clone 1 (from U. ruziziensis) has the highest digestibility potential. The genotypes for the species $U$. brizantha and $U$. decumbens showed high proportions of xylem and sclerenchyma that may reduce their quality as forage.

\section{ACKNOWLEDGEMENTS}

The authors thank Conselho Nacional de Desenvolvimento Científico e Tecnológico (CNPq) [National Counsel of Technological and Scientific Development], Coordenação de Aperfeiçoamento de Pessoal de Nível Superior (CAPES) [Coordination for the Improvement of Higher Education Personnel], and Fundação de Amparo à Pesquisa do Estado de Minas Gerais (FAPEMIG) [Minas Gerais State Research Foundation] for funding and research grants awarded to complete this study. This study was financed in part by the Coordenação de Aperfeiçoamento de Pessoal de Nível Superior - Brasil (CAPES) - Finance Code 001.

\section{DECLARATION OF CONFLICT OF INTERESTS}

The authors declare no conflict of interest. The founding sponsors had no role in the design of the study; in the collection, analyses, or interpretation of data; in the writing of the manuscript, and in the decision to publish the results.

\section{AUTHORS' CONTRIBUTIONS}

All authors contributed equally for the conception and writing of the manuscript. All authors critically revised the manuscript and approved of the final version.

\section{REFERENCES}

AKIN, D. E. Histological and physical affecting digestibility of forages. Agronomy Journal, v.21, p.17-25, 1989. Available from: $<$ https://dl.sciencesocieties.org/publications/aj/abstracts/81/1/ 
AJ0810010017>. Accessed: Mar. 17, 2018. doi: 10.2134/agron j1989.00021962008100010004x.

BAUER, M. O. et al. Anatomical evaluation and nutritive value of four prevailing forage grasses in natural pasture of ViçosaMG. Revista Brasileira de Zootecnia, v.37, n.1, p.9-17, 2008. Available from: <http://www.scielo.br/scielo.php?script=sci arttext\&pid=S1516-35982008000100002>. Accessed: Mar. 17, 2018. doi: 10.1590/S1516-35982008000100002.

BECK, C.B. An introduction to plant structure and development: plant anatomy for the twenty-first century. New York: Cambridge University Press, 2010. 441p.

BRITO, C.J.F.A. et al. Quantitative anatomy and in vitro tissue degradation in elephant grass (Pennisetum purpureum Schumach.) cultivars. Revista Brasileira de Zootecnia, v.28, p.223-229, 1999. Available from: <http://www.scielo.br/pdf/ rbz/v28n2/v28n2a01>. Accessed: Mar. 17, 2018.

BRITO, C.J.F.A et al. Quantitative Anatomy of Leaves and Stems of Brachiaria brizantha (Hochst. ex A. Rich.) Stapf and B. humidicola (Rendle) Schweick. Revista Brasileira de Zootecnia, v.33, p.519-528, 2004. Available from: $<$ http://www.scielo.br/pdf/rbz/v33n3/21473>. Accessed: Mar. 17, 2018

BUKATSH, F. Benerkemgem zeir doppelfarbeing astrablausafranina. Microkosmos, v.61, p.255-256, 1972.

CLIPES, R. C. et al Estimation of the undegradable fraction of neutral detergent fiber of the tropical forages from lignin concentration. Revista Brasileira de Saúde e Produção Animal, v.11, n.4, p.999-1011. 2010. Available from: <http:// www.rbspa.ufba.br/index.php/rbspa/article/view/1740/1026. Accessed: Mar. 17, 2018

FERREIRA, D.F. Sisvar: a computer statistical analysis system. Ciência e Agrotecnologia, v.35, p.1039-1042, 2011. Available from: <http://www.scielo.br/scielo. php?pid=S1413-70542011000600001\& script $=$ sci abstract\&tlng=pt $>$. Accessed: Mar. 17, 2018. doi: 10.1590/S141370542011000600001 .

GRABBER, J.H. How do lignin composition, structure, and cross-linking affect degradability? A review of cell wall model studies. Crop Science, v.45, n.3, p.820-831, 2005. Available from: <https://dl.sciencesocieties.org/publications/cs/ abstracts/45/3/0820>. Accessed: Mar. 19, 2018. doi: 10.2135/ cropsci2004.0191.

GOMES, R.A. et al. Anatomical and morphophysiological leaf blade traits of Panicum maximum genotypes. Pesquisa Agropecuária Brasileira, v.46, p.205-211, 2011. Available from: <https://seer.sct.embrapa.br/index.php/pab/article/ view/2469/6239>. Accessed: Mar. 17, 2018.

HANNA, W.W. et al. Histological examination of fresh forage leaves after in vitro digestion. Crop Science, v.13, n.1, p.98102, 1973. Available from: <https://dl.sciencesocieties.org/ publications/cs/abstracts/13/1/CS0130010098?access $=0$ \&view $=$ article $>$. Accessed: Mar. 17, 2018. doi: 10.2135/cropsci1973. 0011183X001300010031x.

JANK, L. et al. Breeding tropical forages. Crop Breeding and Applied Biotechnology, v.11, p.27-34, 2011. Available from:
$<$ http://www.scielo.br/pdf/cbab/v11nspe/05.pdf $>$. Accessed: Mar. 17, 2018.

JANK, L. et al. Genética em pastagem. Revista USP, p.8693, 2005. Available from: <http://www.file:///C:/Users/User/ Downloads/13393-16367-1-PB.pdf. Accessed: Mar. 17, 2018.

JOHANSEN, D.A. Plant microtechnique. New York: McGraw-Hill Book Company, 1940. 523p.

MAURI, J. et al. Forage quality in cultivars of Brachiaria spp.: association of lignin and fibers with anatomical characteristics. Australian Journal of Crop Science. v.9, p.1148-1153, 2015. Available from: <http://www.cropj.com/ mauri_9_12_2015_1148_1153.pdf $>$. Accessed: Mar. 17, 2018.

MAURI, J. et al. Regrowth age modifies the leaf anatomy of Brachiaria genotypes. Acta Scientiarum. Biological Sciences, v.40, n. e39369, 2018. Available from: <http://periodicos.uem. br/ojs/index.php/ActaSciBiolSci/article/view/39369>. Accessed: Mar. 17, 2018. doi: 10.4025/actascibiolsci.v40i1.39369.

PACIULLO, D.S.C. Anatomical traits related with nutritive value of forage grasses. Ciência Rural, v.32, p.357-364, 2002. Available from: <http://www.scielo.br/pdf/cr/v32n2/ a29v32n2>. Accessed: Mar. 17, 2018.

PACIULLO, D.S.C. et al. Anatomical traits of leaf blade and stem of tropical forage grasses, according to level of insertion on the grass tiller, age and season of growth. Revista Brasileira de Zootecnia, v.31, p.890-899, 2002. Available from: <http://www. scielo.br/pdf/rbz/v31n2s0/21278>. Accessed: Mar. 17, 2018.

SANTOS, F.C. et al. Adaptive leaf anatomical characteristics of Brachiaria ruziziensis (Poaceae) genotypes in different environments. Acta Scientiarum. Biological Sciences, v. 35, n.4, 2013. Available from: $<\mathrm{http}: / /$ periodicos.uem.br/ojs/index. php/ActaSciBiolSci/article/view/18265/0>. Accessed: Mar. 17, 2018. doi: 10.4025/actascibiolsci.v35i4.18265.

SANTOS, F.C. et al. Leaf anatomy and nutritive values of Brachiaria ruziziensis genotypes. New Zealand Journal of Agricultural Research, v.57, p.128-135, 2014. Available from: $<$ https://tandfonline.com/doi/full/10.1080 /00288233.2014.897237>. Accessed: Mar. 17, 2018. doi: $10.1080 / 00288233.2014 .897237$.

SHIRASUNA, R.T. Urochloa. In: Lista de Espécies da Flora do Brasil, 2015, Rio de Janeiro: Jardim Botânico do Rio de Janeiro. Available from: $<$ http://floradobrasil.jbrj.gov.br/jabot/ floradobrasil/FB26029>. Accessed: Mar. 17, 2018.

SOUZA SOBRINHO, F. et al. Genetic variability in Brachiaria ruziziensis for resistance to spittlebugs. Crop Breeding and Applied Biotechnology, v.10, p.83-88, 2010.

SOUZA SOBRINHO, F. et al. Productivity and quality of Brachiaria fodder in the Northern Region of Fluminense. Applied Research \& Agrotechnology, v.2, n.3, p.7-20, 2009a. Available from: $<$ https://revistas.unicentro.br/index.php/repaa/ article/view/1502/1359>. Accessed: Mar. 17, 2018.

SOUZA SOBRINHO, F. et al. Melhoramento de gramíneas forrageiras na Embrapa Gado de Leite. In: EVANGELISTA A. R.; SOUZA, F. F. (Eds.) Forragicultura e Pastagem. Lavras: Editora UFLA, 2009b. p.98-111. 
THAIKUA, S. et al. Preliminary evaluation on digestibility and the relation to morphology and water content of Brachiaria spp. and their heritability. Grassland Science, v.61, p.92100, 2015. Available from: <https://onlinelibrary.wiley.com/ doi/full/10.1111/grs.12082>. Accessed: Mar. 17, 2018. doi: $10.1111 /$ grs. 12082 .

TSUZUKIBASHI, D. et al. Quantitative anatomy, in vitro digestibility and chemical composition of Brachiaria brizantha cultivars. Revista de Ciências Agrárias, v.39, n.1, p.4653, 2016. Available from: <http://www.scielo.mec.pt/scielo. php? script $=$ sci_abstract $\&$ pid $=$ S0871-018X2016000100006 \&lng=pt\&nrm $=\bar{i}>$. Accessed: Mar. 17, 2018. doi: 10.19084/ RCA14141.

VALLE, C.B. et al. O melhoramento de forrageiras tropicais no Brasil. Ceres, v. 56, p. 460-472, 2009. Available from: $<$ http://www. redalyc.org/pdf/3052/305226808013.pdf>. Accessed: Mar. 17, 2018. 